\title{
Det medialiserede museum: digitale teknologiers transformation af museernes formidling
}

\section{Maja Rudloff}

MedieKultur 2013, 54, 65-86

Published by SMID | Society of Media researchers In Denmark | www.smid.dk The online version of this text can be found open access at www.mediekultur.dk

Gennem de sidste tyve år har digitale teknologier fået en stigende og mere betydningsfuld plads i museernes kommunikation og formidling. Denne artikels påstand er, at museumsformidlingens digitalisering kan ses som resultat af en medialiseringsproces, der kan kades sammen med et kulturpolitisk og museumsteoretisk fokus på digital formidling, hvor brugeroplevelse, interaktivitet og deltagelse er centrale begreber. Artiklen argumenterer for, at de digitale mediers anderledes kommunikations-, reprcesentations- og receptionsformer, samt de interaktive og sociale handlemuligheder, de faciliterer for brugerne, medvirker til at transformere museet som institution. Det konkluderes, at relationen mellem museum, samling og brugere kan ses cendret på forskellig vis ved mediernes mellemkomst, og at den sociale handling, som museumsbesøget traditionelt udgør, er transformeret og til dels indordnet nye medieskabte former for kommunikation og handlen. I et mere overordnet perspektiv kan artiklen ses som et bidrag til en fortsat diskussion af den rolle, som museerne skal indtage i et medialiseret samfund.

\section{Indledning}

Gennem de sidste årtier har museernes formidlingspraksis samt de ideer, denne praksis er bygget på, ændret sig. Ideen og tanken om museet som et sted, der huser samlinger (til brug for forskning), er i stigende grad erstattet af tanken om museet som et middel til at 
kommunikere med offentligheden og spille en mere aktiv rolle i samfundet (Ingemann \& Larsen, 2005; Lund, 2009; Christensen, 2009). I forbindelse med dette paradigmeskift er der sket en markant orientering væk fra genstand mod beskuer, fra samling mod formidling. Det er en orientering, der har medført større interesse i og forståelse for den besøgendes oplevelse. Digitale teknologier har i den forbindelse fået en voksende og mere betydningsfuld plads i museerne både som hjælpemiddel til at udføre museumsfaglige opgaver, der vedrører indsamling og registrering, som kommunikationsform med brugerne online og $i$ det fysiske museum, og som hjælpemidler til fortolkning af museernes samlinger. Udviklingen i digitale teknologier hænger sammen med det anderledes fokus på formidling $\mathrm{i}$ museer. Museerne har naturligvis altid formidlet deres samlinger, men formidlingsbegrebet, der før var knyttet til et mere monologisk og docerende dannelsesideal, kædes i dag sammen med dialogiske egenskaber, der er relateret til digitale teknologier.

Med afsæt i den påstand at museumsformidlingens digitalisering kan ses som resultat af en medialiseringsproces, undersøger denne artikel, hvilken indflydelse medialiseringen udøver på hidtil kendte relationer mellem museum, samling og bruger: Hvad sker der med vante repræsentations- og receptionsformer af museernes samlinger, når museumsformidling bliver digital? Hvilke muligheder og dilemmaer rejser mediernes anderledes potentialer for dialog og virtuel tilstedeværelse for museerne og for museernes brugere? Hvilke implikationer har det med andre ord for museernes formidling, at "... information and communication technologies now mediate every dimension of society" (Livingstone, 2009, p. 2)? Med afsæt i disse spørgsmål er formålet med artiklen at bidrage til en teoretisk og empirisk viden om de forandringer og transformationer af mere fundamental institutionel karakter, som implementeringen af digitale teknologier i museernes formidlingspraksis har medført.

Det analytiske blik, der anvendes, er medialiseringsteoriens. Den danske medieforsker Stig Hjarvard betegner medialiseringen af samfundet som værende et af det moderne samfunds centrale forandringsprocesser (2008a, p. 281). Hjarvard er én af flere centrale forskere (bl.a. Couldry 2007; Krotz, 2005, 2007; Livingstone, 2009; Lundby, 2009; Schulz, 2004), der er med til at tegne det medialiseringsteoretiske felt i disse år. Medialiseringsteorien unders $\varnothing$ ger, hvordan medier, og de anderledes kommunikations-, perceptions- og omgangsformer, de medfører, implicerer social og kulturel transformation. I den forstand er medialiseringsteorien egnet til at støtte en udforskning af, hvilke anderledes sociale relationer, kontekster og handleformer, museernes digitale formidling afføder. Medialiseringsteoriens styrke er, at den forstår mediernes påvirkning af samfundet som en overordnet meta-proces, og i den forstand som én blandt mange senmoderne transformationsprocesser, samtidig med, at den insisterer på et snævrere mikro- og mesoanalytisk sigte for at forstå omfanget og implikationerne af disse transformationer.

Med afsæt i en medialiseringsteoretisk fortolkningsramme struktureres analysen over tre hovedområder - brugeroplevelse, interaktivitet og deltagelse - som er centrale i den kulturpolitiske diskurs og i museumslitteraturen om museernes digitale formidling. I Danmark udgør museumspolitikken den normative ramme, inden for hvilken museernes dispositio- 
ner udspiller sig, og forandringer i museumsinstitutionen har derfor også rod i forandringer i det kulturpolitiske felt. Jeg vil derfor, efter en introduktion til det medieteoretiske blik, jeg anlægger, argumentere for, at et øget politisk diskursivt fokus på digital formidling har været medvirkende til at accelerere digitaliseringen af museernes formidling i praksis. Det skal i den forbindelse præciseres, at digitalisering her henviser til den praktiske transformation af analogt kulturarvsmateriale til et digitalt format med henblik på at tilgængeliggøre dansk kulturarv - en proces, der pågår i bredt omfang i danske kulturinstitutioner i disse år (Kulturministeriet, 2009). ${ }^{2}$ Medialisering derimod er et teoretisk begreb, der - på linje med andre meta-begreber som globalisering, modernisering, individualisering (Hjarvard, 2008a, 2008b; Krotz, 2007; Schulz, 2004) - er centralt at bruge som analytisk linse til at forstå, hvilken indflydelse medierne har på samfundets kulturelle og sociale institutioner.

Digital formidling har fået en central rolle i de senere års museumsfaglige diskurs om museernes status og rolle i samfundet. Bortset fra enkeltstående publikationer som Theorizing Digital Cultural Heritage. A Critical Discourse (Cameron \& Kenderdine, 2007) og den danske forskningsantologi Digital formidling af kulturarv. Fra samling til sampling (Lund m.fl., 2009) mangler der imidlertid stadig kritiske diskussioner af de udfordringer og dilemmaer, som digitalisering af museerne rejser. I den forbindelse kan artiklen her betragtes som et nuancerende indspark til medialiseringsdiskussionen, hvor mediernes indflydelse på museet er katalyseret af en ændret kulturpolitisk orientering, som på samme tid reflekteres i den museumsfaglige litteratur.

De analytiske omdrejningspunkter er som nævnt identificeret ud fra en gennemgang af hovedtemaerne i den politiske diskurs og i museumslitteraturen. Derfor udformer artiklen sig overvejende som en teoretisk analyse, der undervejs eksemplificeres af konkrete eksempler fra den danske museumsvirkelighed. Artiklens overvejelser og diskussioner henter dog også vigtig empirisk inspiration i et større brugerstudie på Københavns Museum fra 2010-12, hvor jeg har undersøgt brugernes reception og anvendelse af et stort digitalt formidlingsprojekt og fulgt med i museets refleksioner og overvejelser i samme forbindelse. Efter analyserne og inden den afsluttende opsamling rundes artiklen af med en kort perspektivering, der argumenterer for en gensidig transformations- og påvirkningsproces, hvor museet ikke bare kan ses medialiseret, men også omvendt øver indflydelse på samfundet via en musealisering.

Der findes ikke en entydigt accepteret definition af nye medier, så det skal her præciseres, at jeg ved omtale af nye medier refererer til digitale teknologier, som tillader interaktiv og multimodal kommunikation (lyd, billeder, tekst, animationer m.m.). Her er for det meste tale om online og mobile teknologier, men blandt artiklens eksempler på digital formidling i (primært) danske museer er også interaktive installationer, som ikke nødvendigvis er online, selvom de bygger på digitale teknologier. ${ }^{3}$ Det er vigtigt at understrege, at jeg med prioriteringen af nye medier ikke dermed antyder et brud eller en diskontinuitet mellem de såkaldt nye og gamle (masse)medier (som fx radio og tv). Min afgrænsning skal snarere ses som en refleksion over, at såvel den politiske diskurs som museumslitteraturen identificerer nogle særlige, transformerende egenskaber og potentialer i de nye digitale medieformer. 


\section{En medialiseringsteoretisk tilgang}

Mediatization involves processes of social changes. These changes may have the character of transformations, as the changes incurred by the media may change the direction, the form, or character of the actual social or cultural activities (Lundby, 2009, p. 11).

Inden for medialiseringsteorien adresserer man spørgsmål om, hvorledes mediernes stadigt stigende udbredelse i vores sociale liv og vores samfundsinstitutioner ikke blot medvirker til at mediere - og dermed repræsentere og konstruere - betydning, men derimod integrerer sig i vores dagligdag på en måde, hvor de aktivt er med til at skabe nye sociale strukturer og handleformer (Hjarvard, 2008a, 2008b; Krotz, 2005, 2007; Schulz, 2004; Lundby, 2009). Medialiseringsteoriens mål er således dels at kunne beskrive overordnede udviklingsretninger i samfundet på tværs af forskellige kontekster dels gennem konkrete analyser at kunne demonstrere mediernes indflydelse på forskellige institutioner og dagligdags sfærer af menneskelig aktivitet (Hjarvard, 2008b; Hepp, Berg \& Roitsch, 2011). Medialisering skal ikke forstås som lineære processer eller ensliggørelse på tværs af institutioner og samfund. Den tyske medieforsker Andreas Hepp argumenterer netop for, at selvom medialiseringsprocesser deler fællestræk på tværs af forskellige kulturelle områder og sociale institutioner, er konsekvenserne af medialiseringen ikke nødvendigvis ens. Effekten og graden af medialisering afhænger derudover af egenskaberne ved de specifikke medier, der er tale om. Værdien af medialiseringsteorien ligger ifølge Hepp i dens evne til at "link these detailed studies to a more general analysis of media power within cultural change" (Hepp, 2009, p. 154). På den baggrund må medialiseringsprocesser undersøges gennem komparativ empirisk analyse af adskillige forskellige kulturelle felter. Dette er da også netop, hvad den danske medieforsker Stig Hjarvard gør: I bogen En verden af medier analyserer Hjarvard med afsæt i mediesociologien medialiseringen af politik, sprog, religion og leg. Det er i forlængelse af sådanne konkrete analyser, at en analyse af museets medialisering bliver relevant, og således prioriteres særligt Hjarvards udlægning af medialiseringsteorien i artiklen. Museer kan forstås som eksempler på en samfundsinstitution, en kontekst, hvor sociale roller "tilbydes, forhandles og udleves (performes) inden for særlige rammer" (Bruhn Jensen, 2000, p. 8).

I modsætning til begrebet mediering, som "vedrører den konkrete kommunikationshandling gennem et medie i en specifik, social kontekst" (Hjarvard, 2008a, p. 30), skal medialisering, ifølge Hjarvard, anskues som en længerevarende proces, "hvorigennem institutioner og interaktionsmåder ændres i kultur og samfund som følge af mediernes øgede betydning" (2008a, p. 30). Hjarvard anlægger først et institutionelt perspektiv på medialiseringen og udpeger den dernæst som en særlig samfundsmæssig situation, "hvor medierne på én og samme tid har selvstændiggjort sig til en institution i samfundet samtidig med, at de på afgørende vis sammenvæves med andre institutioners virke" (2008a, p. 23). Følger man denne optik, betegner medialisering således ikke "enhver proces, hvor medierne påvirker samfund og kultur" (Hjarvard, 2008a, p. 23). Medialisering peger på en "scerlig periode og tilstand i kultur- og samfundsudviklingen, hvor mediernes logik får en 
særlig fremherskende indflydelse på samfundets øvrige institutioner" (Hjarvard, 2008a, p. 23). Hjarvards medialiseringsteori kan altså på linje med flere andre medialiseringsforskeres udlægges som en slags helhedsorientering, der forsøger at begribe de makrosociologiske tendenser, som betinger medialiseringen, samtidig med at indvirkningen identificeres på meso- og mikroniveau gennem institutionel analyse. Netop dette perspektiv på medialisering gør teorien særligt velegnet at anvende som overordnet fortolkningsramme af museet som institution, hvilket da også er denne artikels perspektiv. I forbindelse med de konkrete analyseafsnit om oplevelse, interaktivitet og deltagelse er det nødvendigt dels at inddrage en række museumsforskere, der kan supplere den teoretiske forklaringsramme på museumsinstitutionelt niveau, dels at trække på medie- og kommunikationsteori. Slutteligt er det vigtigt at præcisere, at hvor Hjarvard formulerer sin medialiseringsteori med afsæt i de forandringer, der opstår i samspillet mellem de gamle massemedier og nye, digitale medier og disses fælles indflydelse på samfundet, vil jeg her, som nævnt indledningsvis, fokusere på de nye medier og den indflydelse, de har haft på relationen mellem museerne, samlingen og brugerne.

\section{Medialiseret museumspolitik}

Det kulturpolitiske fokus på digitalisering har haft praktiske konsekvenser for museerne siden en revision af museumsloven fra 1984, hvori der blev stillet krav om digital registrering af kulturarven. Ifølge den gældende museumslov fra 2001 (revideret i 2006) er danske statsejede og statsstøttede museer forpligtet til at indsamle, registrere, bevare, forske i og formidle dansk kunst-, kultur- og naturarv (i det følgende sammenfattet under betegnelsen "kulturarv")4. Opmærksomheden mod digitalisering er fortsat op gennem 1990'erne og i begyndelsen af det nye årtusinde, hvor formidlingsaspektet, ifølge forskningschef på Det Informationsvidenskabelige Akademi (IVA), Hans Dam Christensen (2009), har fået stadigt mere vægt i forhold til museets øvrige lovfæstede forpligtelser. Christensen identificerer to spor i museernes digitaliserings- og formidlingsproces, som følger i kølvandet på de kulturpolitiske satsninger: Til at starte med fungerede den digitale registrering og dokumentation primært som et højtspecialiseret arbejdsredskab for museets fagpersonale. Dette indadvendte blik medførte først et fokusskifte fra det konkrete til det digitale objekt og fra fysiske til virtuelle samlinger. Dernæst fulgte et mere udadvendt blik rettet mod formidlingen til publikum (Christensen, 2009). Denne forskydning mod en større brugerrettethed falder sammen med de nye mediers muligheder for anderledes formidling og dialog med publikum. På muserne er der altså skabt mulighed for, at kulturarven både digitaliseres og medieres på nye måder. Samtidig er der sket en medialisering af de praksisser, som museet driver institution på. Det ses både indskrevet i den lovgivning, som museerne er underlagt, og det manifesterer sig rent praktisk. 


\section{Kulturpolitisk prioritering af digital formidling}

I Danmark eksemplificeres medialiseringen af museumslovgivningen først og fremmest gennem det politiske fokus på udvikling af digital museumsformidling: et fokus, der bl.a. ses $\mathrm{i}$ Kulturministeriets og Kulturarvsstyrelsens publikationer om emnet. Rapporten Udredning om museernes formidling fra 2006 har dannet vigtigt afsæt for de senere års kulturpolitiske prioriteringer samt for de igangværende forhandlinger om en ny museumslov. I udredningen anbefaler det af Kulturministeriet nedsatte formidlingsudvalg, at "der ydes tilskud til nye og eksperimenterende udstillingsformer og formidlingsprojekter" under forudsætning af, at der på museerne "sker en sammentænkning af forskellige digitale og fysiske formidlingsformer" samt at "projektets virkning og modtagelse hos museumspublikummet" dokumenteres (Kyed m.fl., 2006, p. 98). En sådan sammentænkning af formidlingsformer begrundes bl.a. med, at "disse typer formidling er [...] med til at forny institutionens rolle og forholdet til borgerne i formidlingen af kulturarven, hvilket kan være et redskab til at få nye brugergrupper i tale" (Kyed m.fl., 2006, p. 116). Det er ifølge udredningen "vigtigt, at museerne forholder sig til brugernes oplevelser for at kunne kommunikere med publikum på en måde, som kan skabe gode oplevelser af kunst, kultur- og naturarven" (2006, p. 82) og yderligere påpeges det, at integrationen af forskellige digitale formidlingsformer $i$ museumsrummet er en udvikling, der bidrager til "at brugerne i højere grad bliver aktive i formidlingssituationen." (2006, p. 116). Det anføres altså, at digitale medier i særlig grad kan være den katalysator, der fornyr de danske museers forhold til brugerne, idet det formodes, at det digitale i højere grad end den traditionelle museums- og genstandsoplevelse fornyr brugernes oplevelse og muliggør interaktivitet og brugerinddragelse.

Udredningen dannede grundlag for den efterfølgende Formidlingsplan, som implicerer syv udpegede indsatsområder med tilhørende støtteordninger og puljer, der bl.a. støtter udviklingen af museernes digitale formidling. Der er afsat over 40 millioner kroner om året fra 2007 til at gennemføre formidlingsplanen, som skal skabe øget adgang og kendskab til kulturarven for danske borgere. Da hovedparten af danske museer er enten statsejede eller statsstøttede, udgør kulturpolitikkens økonomiske støtteordninger en væsentlig faktor for museernes virke i Danmark. Medialiseringen af museernes formidling er således drevet fremad via væsentlige kulturpolitiske prioriteringer og økonomiske incitamenter. Den politiske dagsorden og diskurs bliver i den forstand katalysator for den formidlingspraksis, som udleves på museerne (Skot-Hansen, 2009).

\section{Den digitale museologi - praksis og teori}

Digital kulturformidling er ifølge den danske kulturarvsforsker Niels D. Lund "blevet et mantra" (2009, p. 21), der fremhæves i politisk-strategiske sammenhænge og behandles fra forskellige faglige vinkler. Inden for museumsforskningen er den såkaldt "nye museologi" opstået som en selvstændig genre, der på teoretisk og praktisk vis forsøger at begribe museernes transformation samtidig med, at den på håndgribelig vis markerer de store insti- 
tutionelle forandringer, som museer har undergået de sidste årtier (Vergo, 1989; Ingemann \& Larsen, 2005). I den forstand, pointerer Christensen, har "den traditionelle museumsforståelse, hvor samlingen spillede den primære rolle, faktisk været under forandring længe" (2009, p. 103). Reelt kan det være svært at adskille teori og praksis i museumssammenhæng, fordi begreberne, der anvendes, ofte er både teoretisk og praktisk orienterede - de informerer og påvirker hinanden (Hooper-Greenhill, 2004; Larsen, 2001).

Det senere år har set fremvækst i, hvad jeg her vælger at kalde en "digital museologi": en undergenre af museologien, der beskæftiger sig med det digitale som særligt forskningsfelt. Antallet af konferencer og forskningspublikationer, der fokuserer på digital museumsformidling, antyder det markante fokus, der er kommet på medialiseringsaspekter af museers formidling og på nye mediers betydning i den sammenhæng: Museums and the Web er fx en årligt tilbagevendende konference siden 1997 og Nordic Digital Excellence in Museums Conference (NODEM) har haft seks afholdte konferencer siden 2003. Beskrivelser af museer som transformative (DREAM-konferencen maj 2012), inklusive (The Inclusive Museum Conference august 2012), interaktive (Drotner m.fl., 2011), digitale (Din \& Hecht, 2007), engagerende (Black 2005), genopfundne (Anderson, 2004), deltagende (Simon, 2010), post (Hooper-Greenhill, 2004), nye (Ingemann \& Larsen, 2005), forandrede (Lumley, 1990; Hein, 2000) og konstruktivistiske (Hein, 1998) markerer et fundamentalt skifte i forestillingerne om, hvad museer er, kan og skal være. Samtidig er det tydeligt, at terminologien, der anvendes til at tematisere museers formidling, semantisk trækker på et vokabularium, der ofte bruges til at beskrive digitale teknologier og herunder de forandrede sociale rum og handlemuligheder, som særligt nye medier har faciliteret. Hertil kommer, at museernes publikum og besøgende både i den politiske diskurs og den teoretiske museologi i stigende grad refereres til som brugere, hvilket i kommunikationsteoretisk forstand markerer et skifte fra at tænke på modtagerne af museumsformidlingen som passive recipienter til at tænke på dem som aktive deltagere. Museumsforskningen har således i sig selv undergået en medialisering i den forstand, at forskningens emner og tematiseringer indoptages fra og relateres til brugen af nye medier. Denne medialisering har været influeret af strømninger i andre videnskabelige grene, herunder samtidig kommunikations- og medieforskning, hvor en forståelse af et "aktivt publikum" er blevet udviklet (Hooper-Greenhill, 2004, p. 562). Det indebærer, at publikum ikke længere ses som passive modtagere af mediebudskaber, men at de selv betragtes som aktive medskabere i betydningsprocessen.

I en stor del af museumslitteraturen synes der, i lighed med den kulturpolitiske diskurs i øvrigt, at herske en fælles konsensus om, at nye medier besidder nogle særlige træk og funktioner, som kan opfylde museernes ændrede behov for inddragelse og dialog. De træk har jeg, som allerede nævnt indledningsvis, af analytiske hensyn opsummeret i hovedområderne brugeroplevelse, interaktivitet og deltagelse, hvis potentialer og dilemmaer for transformering af relationen mellem museum, samling og brugere skal diskuteres i de følgende afsnit. 


\section{Brugeroplevelsen - fra én fortælling til mange fortolkninger}

Nye medier har ændret ved mulighederne for, hvordan viden om museernes samlinger kan organiseres og præsenteres samt for brugernes adgang til og omgang med den viden. Digitalisering flyttede i første omgang formidlingens fokus fra det fysiske til det digitale objekt og fra fysiske til virtuelle samlinger (Christensen, 2009), men det var en proces, der skete sideløbende med et opstående behov for nye kommunikationsformer og midler til at formidle fortiden på, end den traditionelle historiske udstilling var eksponent for (HooperGreenhill, 2004). I artiklen "Formens semantik - en teori om den kulturhistoriske udstilling" giver kulturhistorikerne Camilla Mordhorst og Kitte Wagner Nielsen (1997) en karakteristik af den nedarvede, dominerende repræsentations- og kommunikationsform, som den analoge, kulturhistoriske udstilling typisk anvender. Bl.a. gør den analoge udstilling typisk brug af en kronologisk opbygning, tiltaleformen er belærende, og gennem fremlægning af originale objekter fra enkeltstående historiske perioder og/eller begivenheder tilstræbes et udsagn om objektivitet. Udstillingen forekommer at være afsenderløs, og den besøgende inddrages ikke i udstillingen, som tværtimod foregiver at tale på menneskehedens vegne. Idealet er, at historien fortæller sig selv ved hjælp af genstandene: at genstandene i sig selv udtrykker en betydning eller fortæller en (iboende) historie. I en senmoderne museumsvirkelighed, hvor museerne mødes af krav og ønsker om dialog, gensidig meningsudveksling og multifacetterede, individualiserede oplevelser, er formen - som i øvrigt slet ikke tidligere blev opfattet som en form eller orden, "men som en helt igennem fornuftig systematik" blevet en "spændetrøje" for kuratorerne (Mordhorst \& Nielsen, 1997, p. 16). Den klassiske orden eksisterer stadig, men den udfordres i stigende grad af behovet for andre formidlingsformer.

Digitalisering af samlinger og arkiver kan medføre nedbrud af gældende taksonomier og hierarkier og kaste lys over det konstruktivistiske aspekt af tidligere tiders måder at organisere viden på. Nye teknologiers muligheder for at annotere, emneopdele og søge på tværs kan skabe nye meningssammenhænge og hjælpe til at se samlinger i et nyt og mere nuanceret lys. Netop fordi digitalisering giver brugerne valgfrihed i deres informationssøgning, fremhæves digitale medier også ofte i formidlingsdebatten for de muligheder for individualisering og personliggørelse, som de tilbyder (Lund, 2009; Skouvig, 2009; Cameron, 2003). Den australske museumsforsker Fiona Cameron beskriver, hvordan for eksempel online søgesystemer har fremmet brugernes søgevalg og åbnet op for en "udvidet fortolkningsramme" (2003, p. 327), som hun bl.a. beskriver således:

With hypertext and other forms of information architecture, curators are able to present a range of narratives linked to other texts and resources. The arbitrary nature of the museum's voice is acknowledged through the inclusion of other voices and sources. An oversimplified interpretation of the history of objects is altered by engagement with pluralistic narratives, validation of alternative views on collections, and a shift to self-perception and analysis through interactivity (Cameron, 2003, p. 333) 
Selvom Cameron specifikt adresserer databaser, er det nemt at se, hvordan digitale mediers facilitering af vidensorganisering på måder, der bryder med traditionelle, hegemoniske kronologier, kan kædes sammen med en bevægelse væk fra ensidige fortælle- og repræsentationsformer, hvor museet som autoritet præsenterede den korrekte udlægning af fortiden. Frem for én fortælling er der - helt på linje med en poststrukturalistisk tankegang - mulighed for mange fortællinger, når fortolkningen lægges ud til brugerne. Den flersidede fortælling understøttes af mediernes ofte multimodale oplevelsesmodi. Hertil kommer nytolkningsaspektet, idet enhver medieret gengivelse kan betragtes som en remediering, der præsenterer det gengivne i en ny formidlingskontekst (Bolter \& Grusin, 1999). Som den danske medieforsker Jack Andersen påpeger: "digitaliseringshandlingen både genfortæller og skaber en ny fortælling" (2009, p. 67). Digitaliseringens genfortælling åbner således også op for en klassisk diskussion om original/kopi.

\section{Original eller digital?}

Når museerne digitaliserer deres samlinger og stiller dem til rådighed på fx internettet, sker der noget med repræsentationen af genstandene og dermed med receptionen og fortolkningen af kulturarven. Digitalisering har genintroduceret spørgsmål om aura, original og autenticitet og om oplevelsen af den oprindelige og ægte genstand versus den digitale kopi (Cameron, 2003; Witcomb, 2007; Smith, 2006). Problemstillingen blev rejst allerede i starten af 1900-tallet med Walter Benjamins berømte artikel Kunstverket i dets teknisk reproducerbarheds tidsalder (1936). Det var en debat, der blussede op igen med internettets opkomst, i første omgang i form af bekymring over, hvorvidt det digitale helt ville flytte museets fokus eller endda overflødiggøre museet til fordel for digitale samlinger eller virtuelle museer (Skot-Hansen, 2009). Debatten om en eventuel cybermuseologi blev imidlertid hurtigt afløst af andre problematikker vedrørende museernes virkemåde og status i samfundet i takt med, at det blev tydeligt, at digitale medier blev integreret i museernes formidlingspraksis snarere end erstattede dem. I forhold til medialiseringen af samfundets institutioner er det ifølge Hjarvard generelt karakteristisk, at virtualiseringen sjældent er total, og at institutionerne i de fleste tilfælde beholder en fysisk base som det vigtige grundlag for social praksis:

\footnotetext{
What is new is that these places and buildings now interplay with virtual places and spaces, and the reality and forms of interaction that take place in the virtual world will also have consequences for social praxis in the physical locality (2008b, p. 129).
}

Museer har i den forbindelse måttet forholde sig til dilemmaer, der bl.a. vedrører forholdet mellem fysisk genstand og digital repræsentation.

I forhold til genstandsrepræsentation og -reception, er der ingen tvivl om, at oplevelsen af en tredimensional fysisk genstand er anderledes end oplevelsen af dens todimensionale, digitale gengivelse. Et stadigt voksende forskningsfelt i materialitet og nærvær i relation til 
museumsoplevelsen fremhæver i den forbindelse fysiske objekters særlige potentiale for at skabe engagerende og affektive kropsligt funderede oplevelser (fx Taylor, 2010; Smith, 2006; Paris, 2006). Det er da også blevet fremført, at netop dét, som museet kan og skal overleve og differentiere sig på i et digitaliseret og oplevelsesøkonomisk samfund, er den originale genstand (Paris, 2006; Smith, 2006), mens det af andre fremføres, at de forskellige oplevelsesmodi ikke nødvendigvis bør opfattes som værende i et konkurrenceforhold, men at de kan berige og supplere hinanden (Frost, 2010; Witcomb, 2007). Den australske forsker Andrea Witcomb er en af modstanderne mod det binære skel, som ofte sættes mellem den virtuelle og materielle verden i museumsformidlingen, hvor det digitale enten ses som en trussel imod den etablerede museumskultur og praksis eller som midlet, hvorigennem museet kan sikre sin egen fornyelse og overlevelse ind i det 21. århundrede. Gennem analyse af digitale installationer i museumsudstillinger argumenterer hun for, at disse kan "... enable the creation of a physical, mental, and emotional space which prepares the audience for a sensitive re-reading of those objects that are on display" (Witcomb, 2007, p. 46). Det digitale forstås således her som en mulighed for at udvide og udbygge oplevelsen af det fysiske objekt, samtidig med at det lægger op til en ny form for interaktion, hvor det digitale og det fysiske, frem for at blive defineret i et modsætningsforhold, spiller sammen.

\section{Museumsoplevelsen i 3D}

Alligevel genaktualiseres autenticitets- og genstandsdebatten, som teknologierne udvikles og forfines. For, som Christensen polemisk antyder, er den repræsentationsteknologiske virkelighed i dag den, at mange objekter, som også er tilgængelige i det fysiske udstillingsrum, opleves bedre ved hjælp af digital teknologi (2009). Christensen peger selv på eksemplet Mona Lisa, Leonardo da Vincis berømte renæssancemaleri, som hænger på Louvre i Paris. Billedet er gjort tilgængeligt på websiden Mona Lisa. A Scientific Examination (projektet fra 2006 er en del af National Research Council of Canada's projekt Picture Perfect Science), hvor bl.a. infrarøde billeder viser en detaljerigdom, som det for det første ville være umuligt at se med det blotte øje. For det andet er det spørgsmålet, hvorvidt den besøgende overhovedet kan se billedet særligt tydeligt på dets fysiske placering bag tykt panserglas og den omkransende menneskemængde, der typisk er at finde foran maleriet (Christensen, 2009). Et andet eksempel er Google Art Project som med højteknologiske værktøjer har filmet såvel udstillingssale som kunstværker i en række af verdens mest prominente museer, heriblandt Statens Museum for Kunst. Udover at give brugere hjemmeadgang til at besøge museer i verdensdele langt fra deres egen, er tanken, at det skal give dem en mere dynamisk oplevelse af at bevæge sig rundt på museet end fx søgning i et digitaliseret museumsarkiv kan give. Kunstværkerne er fotograferet i meget høj opløsning, og en højtudviklet zoomteknologi betyder, at brugeren kan komme langt tættere på billedet, end det ville være tilfældet i det fysiske museumsrum. Det er i dag yderligere muligt at forestille sig, at forfinelsen i udviklingen af digitale teknologier fører til, at digitale simulationer i eksempelvis 3D 
kan træde i stedet for genstande, som af konservatoriske hensyn er for skrøbelige til at blive udstillet. Tilgængeligheden til samt mulighederne for at opleve museernes genstande og en fælles kulturarv er altså udvidet fundamentalt ved mediernes mellemkomst.

\section{Interaktivitet - et udvidet begreb}

Interaktivitet fremhæves ofte i forbindelse med nye medier, fordi interaktiviteten bliver lettere, hastigere og mere en-til-en, samtidig med at de giver brugerne mulighed for at skabe indhold (Lievrouw \& Livingstone, 2006; McMillan, 2006). Som den tyske medieforsker Winfried Schulz præciserer: "the interactivity of the new media turns recipients into communicators" (2004, p. 94). Ifølge den danske medieforsker Jens F. Jensen "bruges begrebet 'interaktivitet' eller sammensætningen 'interaktive medier' oftest til at betegne et bestemt træk ved disse nye medier, der sætter en forskel i forhold til traditionelle medier" (1997, p. 45). Det betyder ikke, at analoge medier som tv og radio ikke besidder et interaktivt potentiale, men snarere at mulighederne for interaktivitet er udvidet med nye medier, hvor brugerne også kan være medskabere af indhold (McMillan, 2006). Interaktivitet er således ikke et nyt begreb, og dets anvendelse i forskellige sammenhænge komplicerer forståelsen af, hvad det egentlig er, nye medier kan og dermed også konsekvenserne af deres anvendelse i fx museumsformidling. I en indkredsning af begreberne interaktion og interaktivitet lokaliserer Jensen begrebernes oprindelse $i$ tre forskellige fagtraditioner, der automatisk implicerer forskellige forståelser for deres indhold og anvendelse: Kort sagt vedrører "interaktion" inden for sociologien ansigt-til-ansigt interaktion mellem to mennesker (Jensen, 1997; Krotz, 2005). Inden for informatikken og medievidenskaberne bruges både "interaktion" og "interaktivitet" til at beskrive forskellige former for kommunikativ udveksling mellem brugere og medier (CMC) eller mellem bruger og maskine ( $\mathrm{HCl}$ ) (Jensen, 1997; se også Krotz, 2005). I en museumskontekst kan alle tre former for interaktion/interaktivitet sameksistere i museumsbesøget (ligesom digitale, interaktive projekter kan designes således, at de specifikt understøtter flere oplevelsesformer). Hvorvidt de sameksisterer, afhænger bl.a. af de digitale mediers evne til at facilitere forskellige former for interaktion på samme tid.

\section{Forskudte interaktionsformer}

Tanken om interaktion mellem museernes samlinger og de besøgende er ikke ny (Witcomb, 2004, p. 353), men der er sket nogle forskydninger i, hvordan interaktivitet forstås og praktiseres på museerne. Museumsforskerne Christian Heath og Dirk vom Lehn (2010) påpeger, at begrebet "interaktivitet", når det anvendes i en museumskontekst, i dag i stigende grad synes at referere til menneskers interaktion med teknologier $(\mathrm{HCl})$, hvilket de tilskriver de seneste års øgede implementering af digital formidling i museerne. Jeg vil i forlængelse af Heath og Lehns påstand hævde, at den sociale interaktion blandt museumsbesøgende ændrer sig, når digital interaktivitet bliver en del af museumsoplevelsen. Et definerende 
træk ved det traditionelle on-site museumsbesøg er, at det er en overvejende social oplevelse: "many visitors come to a museum for unstructured social activity, museums typically create spaces and opportunities for friends and strangers to talk, eat, rest, read, shop and more" (Howes, 2007, p. 72). Hovedparten af museumsbesøgende besøger museet i par eller grupper, med hvem de interagerer, henter information fra, lærer af og sammen med under besøget (Heath \& Lehn, 2010; Falk \& Dierking, 2000; Moos \& Lundgaard, 2010).

Flere museumsundersøgelser peger på, at visse former for digitalt baseret interaktivitet ikke altid understøtter social interaktion, deltagelse og samarbejde mellem brugere (Heath \& Lehn, 2010; Keitel, 2010). Den medieskabte og -faciliterede interaktion ompositionerer med andre ord de sociale aktører i museumsbesøget. Det ses i formidlingssituationer, hvor interaktiviteten frem for at være interpersonel rettes mod digitale standere og skærme i udstillingen, eller ved audiovisuel formidling via mp3-afspillere eller smartphones, hvor brugernes opmærksomhed rettes mod et lydspor eller mod gps-styret information på den håndholdte skærm. Hvor den direkte interaktion med mediet giver brugeren lettere adgang til museernes information, og hvor samme interaktion (mellem medie og bruger) altså tillader individet større valgfrihed og udbygning af personlige interesser, er der i nogle tilfælde en risiko for, at dette sker på bekostning af den sociale interaktion brugerne imellem. Eftersom den direkte ansigt-til-ansigt interaktion mellem brugere anses for vigtig i særligt læringssammenhænge, må dette betragtes som et væsentligt dilemma. Derfor har der i de senere år været en større interesse for, hvordan digitale teknologier kan designes, så de understøtter den sociale dimension af museumsbesøget (Ciolfi, Bannon \& Fernström, 2008).

\section{Databasen: fra historisk kilde til kommunikationsform}

Den amerikanske museumsforsker Olivia C. Frost argumenterer netop for, at selvom interaktivitet mellem brugere og digitaliserede online museumsdatabaser kan medføre frugtbare læringspotentialer, så kan det være et problem, at hjemmebrugeren ikke kan gøre brug af den ekspertise, som museumspersonalet repræsenterer til at underbygge sin søgning og viden om de museumsobjekter, der fremsøges. Den danske kulturhistoriker Laura Skouvig påpeger, at formidlingsperspektivet ændrer sig, når fx arkivmateriale, hvis primære tidligere funktion var "at være blot et reservoir til brug for forskning eller bearbejdning til endeligt resultat af historikeren" transformeres til online database, fordi "den autoritet, som faghistorikeren har kunnet hævde - som den der kan forstå, fortolke og formidle det fragmenterede kildemateriale - forsvinder, når kildematerialet direkte tilgængeliggøres" (2009, p. 84). Dilemmaet aktualiseres af, at en ny og stadigt voksende gruppe af borgere kun informerer sig via digitale medier. Kulturarvsstyrelsens webrugerundersøgelse fra 2010 identificerer således en helt ny gruppe af webbrugere, som kun besøger museer online, og dermed aldrig er i umedieret kontakt med museumspersonalet (Moos \& Lundgaard, 2010, p. 8). 
Selvom Frost og Skouvig fremhæver websteder og online databaser, som de mest oplagte eksempler på et problemfelt, hvor den museumsfaglige støtte er forsvundet i fortolkningssituationen, gælder den ikke blot internettet. På in-situ kulturarvssteder (fx arkæologiske udgravninger eller på byvandringer) er en personlig guide ikke længere nødvendig. Det medfører stor fleksibilitet for brugerne, som ikke skal tilpasse sig et skemalagt tidspunkt for oplevelse af kulturarven. ${ }^{5}$ Håndholdte guides og gps-styrede mobiltelefoner fjerner imidlertid også det personlige led i kommunikationen, idet de tillader uledsagede omvisninger - både on-site og off-site - hvor brugerne fx modtager information på deres smartphones eller mp3-afspillere. Teknologiudviklingen åbner mulighed for, at museet kan møde brugerne mange steder, og der ses stadigt flere eksempler på, at brugerne kan opleve museet uden for museumsbygningens traditionelle rammer, hvor musealt indhold kan tilgås fra en formidlingskontekst, der er meget ulig den traditionelle museumsudstillings. I de tilfælde er det tidligere personlige ekspertformidlede møde mellem museumssamling og bruger dog udskiftet af et medie, som potentielt ændrer karakteren af den viden, der formidles.

\section{Museumsbesøgets allestedsnærværelse}

Det er et særligt kendetegn ved nye medier, at de udgør en stadig mere sømløs del af vores hverdag og sociale omgangsformer. Inden for globaliserings- og modernitetsforskningen er det bredt anerkendt, at digitale teknologiers allestedsnærværelse har ændret fundamentalt på mulighederne for kommunikation og derved også på mulighederne og formerne for social interaktion på tværs af tid og rum (Lievrouw \& Livingstone, 2006; Bruhn Jensen, 2000). Ifølge Hjarvard er det et af medialiseringens centrale karakteristika, at medierne tilføjer "an expansion of the opportunities for interaction in virtual spaces and a differentiation of what people perceive to be real" (2008b, p. 111). For museerne medfører denne ophævelse af tidslige og rumlige grænser, at brugerne ikke længere er forhindret af åbningstider og fysisk tilstedeværelse, når de ønsker at benytte sig af museernes formidlingstilbud. En samtidig museumsforståelse må altså søge at begribe praksis som én, der bevæger sig i flere rum på samme tid. I takt med at museer ved mediernes mellemkomst spreder sig ud over de traditionelle arkitektoniske rammer for museumsbesøget, ændrer det forholdet mellem museet og dets brugere. Den rumlige og kontekstuelle forskydning i museernes og brugernes kommunikative interaktion implicerer, at museet entrerer brugerens rum frem for, som tidligere, at brugerens besøg, og dermed reception og fortolkning, foregik i et rum, der var organiseret af museet. En konsekvens heraf er, at hvor det traditionelle bygningsbaserede museum kunne kontrollere museumsbesøgets fysiske kontekst (omend naturligvis ikke museumsgæstens reaktion på denne kontekst), så mister museet mulighed for at påvirke de omgivelser, som udgør den rumlige præmis for de besøgendes reception og betydningsskabelse, når besøget sker på afstand (online) eller i en anderledes fysisk kontekst (Parry \& Arbach, 2007). 


\section{Deltagelse - en demokratiseret vidensform?}

Vores sociale liv er siden internettets fremkomst blevet stærkt påvirket af medier, der giver os mulighed for at dele viden og information samt danne og opretholde sociale fællesskaber på tværs af afstande. Kommunikationsformerne har ændret sig med de nye medier, bl.a. fordi digitale medier tillader deltagelse ad flere kanaler og fra forskellige aktører på én gang. Det betyder, at både afsender og modtager kan influere på kommunikationen og meddelelsen (Hjarvard, 2008a). Netop dette aspekt ved de nye medier har haft afgørende indflydelse på tankerne om det demokratiske potentiale, som digitale teknologier indbefatter. Det gælder også for museerne.

Debatten præges her af ideer om teknologien som det ultimative redskab til fri udveksling af viden og opnåelse af demokrati og frihed. Denne antagelse kan synes paradoksal taget i betragtning, at deltagelse på internettet og sociale medieplatforme generelt følger et 90-9-1-princip, som implicerer, at 90 pct. af brugerne blot modtager, 9 pct. kommenterer eller tilføjer, og 1 pct. skaber materiale - et fænomen som usability-eksperten Jakob Nielsen kalder "participation inequality" (Nielsen, 2006). Der er ingen anledning til at tro, at deltagelsen i web-faciliterede museumsprojekter skulle være større (Simon, 2010). Det rejser spørgsmål om, hvem man egentlig når med anvendelsen af online teknologier i museumsformidlingen? Mere generisk kunne man spørge til, hvor demokratiske digitale medier i virkeligheden er?

Et dilemma, som stadig sjældent rejses i forskningslitteraturen, der vedrører digital brugerinddragelse på museer, er, at den frem for at inkludere, tværtimod direkte kan udelukke befolkningsgrupper, som ikke har adgang til det nødvendige udstyr, ikke har de fornødne færdigheder, eller ganske enkelt ikke har lyst til at deltage på den måde (Brøgger, 2009; Frost, 2010). Spørgsmålet om digitale teknologiers evne til demokratisering adresseres fra en mere generel og makro-orienteret position i den såkaldte "Digital Divide"-debat. Debatten problematiserer allokering af og tilgang til digitale ressourcer på såvel nationalt som internationalt plan, og det fremføres, at digitale medier kun er demokratiske i den forstand, at alle har lige adgang til dem og den videndeling, de faciliterer (Schulz, 2004; Couldry, 2007, p. 384). Man kan altså hævde, at nye medier kan udelukke nogle brugere, som ikke kan deltage i museets digitale tilbud, enten fordi de ikke evner eller måtte ønske det, eller fordi de ikke besidder værktøjerne eller kompetencerne.

\section{Nye perspektiver på samlingen}

Ikke desto mindre er der de senere år kommet et større fokus på de muligheder for brugergeneret indsamling, som digitale medier tilbyder. Hvor interaktivitet giver brugerne mulighed for at udøve personlige valg i deres museumsbesøg, tillader deltagelse deciderede bidrag fra brugerne, som derigennem får indflydelse på de narrativer, som museet repræsenterer, og dermed på den viden om en fælles kulturarv, der skabes og viderebringes. Disse videndelende egenskaber ved nye og sociale medier har givet museer mulighed for at skabe 
kontakt til lokalsamfund, samfundsgrupper og interessefællesskaber og åbnet et potentiale for udveksling på tværs af kulturer, geografi og generationer (Frost, 2010). De muligheder for selvpublicering, som digitale medier stiller til rådighed, gør det muligt for museer at invitere langt større og mere differentierede grupper af brugere til at bidrage med deres eget materiale. Ydermere kan invitation til deltagelse medvirke til at ændre museernes image i den bredere befolkning.

Når brugere inviteres til at deltage, kan det skabe ny viden om og nye perspektiver på museernes samlinger (Rudloff, 2012). Deltagelse kommer i mange former og grader fra, at brugerne kan tagge og kommentere på museers materiale, til at brugerne selv skaber indhold eller uploader billeder til museet (Simon, 2010; Løssing, 2009). Et fællestræk for intentionerne bag digitale outreach-og indsamlingsprojekter er, at brugerne skal tildeles flere handlemuligheder og mere indflydelse på tilskrivningen af betydning om en fælles fortid. Struer Museums "Byskriveren" og Københavns Museums "V/EGGEN" er eksempler på projekter, hvor brugerne, og i særlig grad lokalbefolkningen, inviteres og opfordres til at bidrage til de respektive byers historie med personlige erindringer, anekdoter, digitalt materiale og kommentarer til eksisterende materiale. ${ }^{6}$ Fælles for begge projekter er i øvrigt, at de er til stede på flere platforme og således møder brugerne både online og som fysisk møde via digitale interaktive skærme i henholdsvis museets fysiske udstilling (Byskriveren) og i byrummet (V/AGGEN). Inddragelse af brugerne kan bringe museet tættere på sit publikum, men brugerinddragelse påvirker også organisationen indadtil på flere måder, fordi de medfører nogle helt nye udfordringer og arbejdsprocesser, hvor det museumsfaglige personale må afgive autoritet og indtage en mere faciliterende rolle, hvor de skaber rammerne for, at brugerne kan bidrage og komme til orde. Det ses bl.a. eksemplificeret på Københavns Museum, hvor en museumsinspektør har været ansat næsten udelukkende til at styre opgaver og aktiviteter relateret til det digitale formidlingsprojekt VÆGGEN.

Når museerne giver brugerne adgang til at deltage, sker der altså en forskydning i de sociale aktørers handleformer og -muligheder. At balancen mellem museum og brugere skifter, betyder ikke nødvendigvis, at den bliver lige eller tildeles lige værdi (Henning, 2006; Hjarvard, 2008a). Det modtagende museum har stadig den primære autoritet i forhold til emnevalg, udvælgelse og tilgængeliggørelse af det brugergenererede materiale og dermed den meningssammenhæng, som disse bidrag repræsenteres i. Ifølge Hjarvard skal dette ulige forhold ses som en afspejling af, at deltagerne i enhver social interaktion, uanset om denne er medieret eller ej, "altid indtræeder i og udøver sociale roller, og at de i kraft af disse roller har forskellige muligheder for at påvirke interaktionens forløb og resultat" (2008a, p. 41). Også i museernes daglige praksis kan dette forhold ses helt konkret eksemplificeret ved, at det i langt overvejende grad fortsat er dem, der beslutter, hvilken kulturarv, der skal indsamles, bevares og registreres samt herefter digitaliseres og eventuelt fremvises på museets hjemmeside. Det ses fx sjældnere, at brugerne har indflydelse på, hvad der skal bevares eller på kuratoriske processer - medmindre det er en del af et specifikt formidlings- 
projekt. Mediefaciliteret deltagelse har dog ændret ved museernes autoritet og ved deres relation til brugerne.

\section{Andrede relationer: fra autoritet til facilitator}

Brugerdeltagelse på museer rejser en række problematikker, der særligt vedrører spørgsmål om autoritet, kvalitet og relevans. Forskning viser, at museumsbesøgende har høje forventninger til museers originalitet, integritet og ekspertise samt til kvaliteten af den formidling og de oplevelser, som de kan få på museet (Dierking \& Falk, 1998). Traditionelt har det været således ifølge Frost, at "when an object or unit of information resides in a collection, that collection serves a filtering or sanctioning role" (2010, p. 243). Museumsbesøgende stoler på museernes ekspertise i udvælgelsen og organiseringen af den kulturarv, der fremvises offentligt. Den ekspertviden, som museet står for, har traditionelt været med til at forsikre brugerne om, at de genstande og værker, som de kan se på museumshjemmesider, i udstillinger eller andre formidlingssammenhænge er blevet nøje udvalgt på baggrund af deres kvalitet, repræsentativitet eller andre kriterier (Frost, 2010; Dierking \& Falk, 1998). I brugerinddragende museumsprojekter, hvor alle i princippet kan deltage, har de besøgende ikke længere den samme garanti for, at det, de ser på, repræsenterer det bedste i genren eller har mulighed for at vurdere, hvorvidt den information, de modtager, er korrekt eller sand.

Digitale brugerinddragende projekter kan medføre, at der modtages utroligt mange billeder, som ikke nødvendigvis alle er af særlig høj kvalitet, som er emnemæssigt irrelevante, eller som mangler mangfoldighed og variation i motiverne, hvilket er en konsekvens af de muligheder for at "skyde løs", som digitalkameraet tilbyder. Det er bl.a. tilfældet ved det føromtalte projekt VAGGEN, hvor en stor andel af det brugergenererede billedmateriale omfatter tilnærmelsesvis ens og relativt upersonlige motiver af solopgange, vejrlig, mennesketomme gader, bygninger og fugle- og insektliv. Samtidsindsamling rejser nye fundamentale spørgsmål for museernes som: Hvem skal deltage? Med hvad? Og om hvad? Og det fører videre til relevansen og kvaliteten for dem, der skal se på billederne. Relevans og kvalitet skal være med til at sikre museernes målsætninger i brugerinddragelsen, men også brugerne skal opleve, at museumsprojektet er værd at besøge (Brøgger, 2009; Rudloff, 2012). Her må museerne indtage nye roller i frasorteringen af materiale, men det kan være en svær situation først at invitere folk til at deltage og derefter redigere deres billeder væk. Museer har som kulturinstitutioner et særligt ansvar i forhold til, hvad der skal indsamles og bevares i fremtiden. Når brugere inviteres til at deltage med materiale til samlingerne, kan der opstå svære spørgsmål vedrørende, hvem der har autoriteten til at udvælge, hvad der er relevant at bevare for fremtiden. Hvis deltagelsen ikke har klare rammer, kan det, der skulle være en god og positiv oplevelse, vendes til det modsatte (Simon, 2010; Rudloff, 2012). 


\section{Musealisering af samfundet}

Som det påpeges af de engelske museumsforskere Ross Parry og Andrew Sawyer (2005), har museer altid været adaptive medier, der, siden deres oprindelse i renæssancens kunstkamre, er blevet formet af de forhåndenværende repræsentations- og kommunikationsredskaber? De seneste års udvikling i ikke blot digitale teknologier, men også en sideløbende udvikling i samfundsteoretiske og kulturpolitiske forhold, har imidlertid skabt en særlig situation, der i hidtil uset hast har influeret signifikant på museernes praksis, status og relationen til brugerne. Således har de digitale teknologier på bare to generationer udviklet sig til at blive et definerende træk ved det moderne museum (Parry og Sawyer, 2005).

Medialisering er dog, som nævnt indledningsvis, blot én af flere sideløbende og gensidigt forbundne samfundstransformerende processer. Samtidig med at museet påvirkes af processer som globalisering, individualisering, kommercialisering og modernisering, kan man argumentere for, at der omvendt er sket en musealisering af samfundet og kulturen. Det ses $\mathrm{fx}$ af en stadig stigende opmærksomhed mod bevaring af vores fælles materielle og immaterielle kulturarv (Federspiel, 2012; Huyssen, 1995) - alene "arv"-tanken er ny og opstod først i kølvandet på første verdenskrig. Internationalt bevidnes denne opmærksomhed af det stadig voksende antal chartrer, der udgår fra UNESCO, som er det overordnede organ for fokus på bevaring af verdensarven. På dansk jord har det stadigt større fokus på bevaring og synliggørelse af en fælles kulturarv bl.a. resulteret i, at området i 2002 med Kulturarvsstyrelsen fik sin egen selvstændige og fælles styrelse (styrelsen hedder fra d. 1.1.2012 Kulturstyrelsen).

Historikeren Andreas Huyssen kæder denne musealisering af samfundet sammen med et senmoderne stadigt mere komplekst informationssamfund, hvor behovet for forankring i noget stabilt og uforanderligt er vokset. Aldrig tidligere har der været en lignende optagethed af fortiden, hvilket kommer til udtryk i en nostalgisk fortolkning og forståelse af kulturarven som identitetsskabende og konsoliderende. Med afsæt i den tyske filosof Hermann Lübbe argumenterer Huyssen for, at musealiseringen ikke længere blot er knyttet til museumsinstitutionen i snæver forstand, men derimod har infiltreret alle aspekter af vores hverdagsliv (Huyssen, 2003). Forandringen i museumsinstitutionen og opbruddet med traditionelle formidlingsformer kan således ikke blot forstås som et ensidigt resultat af en medialiseringsproces, men den er et led i en større senmoderne identitetskrise og følgelig kæde af gensidigt influerende transformationsprocesser.

\section{Afslutning}

I det foregående har jeg med analytisk og teoretisk afsæt i kulturpolitiske og museumsteoretiske forestillinger om brugeroplevelse, interaktivitet og deltagelse argumenteret for museets medialisering og diskuteret en række af de muligheder og dilemmaer, som anvendelsen af digitale teknologier rejser i museernes formidlingspraksis. De digitale mediers anderledes kommunikations-, repræsentations- og receptionsformer, samt de interaktive 
og sociale handlemuligheder, de faciliterer for brugerne, har medvirket til at transformere museet som institution. Det fremstår tydeligst i relationen mellem museum, samling og brugere, som kan ses ændret på forskellig vis ved mediernes mellemkomst.

Selvom museer stadig organiserer og formidler deres samlinger i udstillinger, er det medialiserede museumsbesøg forandret til at være meget mere end et besøg i den fysiske institution. Således er også den sociale handling, som museumsbesøget traditionelt udgør, transformeret og til dels indordnet nye medieskabte former for kommunikation og handlen. I dag starter museumsbesøget ofte allerede inden, man bevæger sig hen til museet, og selve oplevelsen af og omgangen med museernes kulturarv har generelt udvidet sig med den ekspansion af muligheder for repræsentation, uafhængig af tid og sted, som digitale teknologier har stillet til rådighed. Det digitale muliggør, at museerne kan organisere og repræsentere deres genstande på måder, der tilbyder anderledes og mere individuelt tilpassede oplevelsesforløb. Men digitale repræsentationer af originale tredimensionale genstande skaber også forskydninger i formidlingens oplevelsesmodi og ændrer ved mere sansemæssige aspekter af oplevelsen. Udvidelsen af museernes fysiske grænser tildeler brugerne mere fleksibel mulighed for at opleve museerne, men den forskyder også interaktionen fra den direkte ansigt-til-ansigt kommunikation mellem henholdsvis de museumsbesøgende internt og mellem bruger og fagpersonale mod interaktionsformer, der i stigende grad er medierede eller foregår direkte mellem bruger og teknologi. Det formindsker brugernes mulighed for direkte personfaglig understøttet formidling af samlingerne - særligt for den voksende gruppe af brugere, som kun besøger museer online. Det dialogiske potentiale, som medierne tilbyder, har givet museerne mulighed for at invitere brugerne til at deltage i ny og fælles vidensproduktion, men netop brugerdeltagelsen har også medført, at museernes autoritative rolle er blevet udfordret, og at de i højere grad må indtage en ny rolle som facilitator og moderator af viden. Museumsoplevelsen har ændret karakter i takt med, at den er blevet indordnet nye medieskabte former for kommunikation. I den forbindelse er det vigtigt at understrege, at medierne ikke blot har tilbudt nye medierings- eller remedieringsformer, men at selve den sociale og kulturelle handling og praksis, som museumsbesøget traditionelt har udgjort, er blevet udvidet, omdefineret og derved ændret fundamentalt.

Digitale teknologier udvikler sig hele tiden og med dem de muligheder for oplevelse, interaktivitet og deltagelse, som museerne stiller til rådighed. Diskussionen om nye mediers transformerende effekt på museet som institution er dermed på ingen måde udtømt med denne artikel: Det er tværtimod en forhåbning, at de dilemmaer, som her er blevet rejst, kan fungere som et afsæt for en fortsat diskussion af den rolle, som museerne forventes at indtage i et medialiseret samfund. 


\section{Noter}

1. Om danske museers formål og opgaver se yderligere Museumsloven kap. 1, $₫ 2$ : https://www.retsinformation.dk/forms/r0710.aspx?id=12017\#K1.

2. Fra et videnskabsteknisk perspektiv betegner digitalisering processen at beskrive fænomener ved hjælp af tal, som i sin enkleste form kan være 0 eller 1 (Finnemann, N.O. (2005). Internettet i mediehistorisk perspektiv. Frederiksberg: Forlaget Samfundslitteratur).

3. Ved at tilgå "nye medier" under ét anlægger jeg desuden en bredere tilgang end den såkaldte "medium theory" (blandt andre Marshall Macluhan og Joshua Meyrowitz), der er særligt optaget af enkelte mediers virkemåder og af, hvorledes det enkelte mediums særlige kommunikations- og interaktionsform bliver medproducent af betydning.

4. Der findes ingen entydig definition af kulturarvsbegrebet, men her anvendes Kulturministeriets definition af kulturarv: "Kulturarven er de spor og vidnesbyrd om naturens udvikling, og om menneskelig aktivitet og tænkning, som de manifesterer sig i fx skrift- og billedkultur, i kunstneriske udtryk, i redskaber og i bygninger" (Udredning om bevaring af kulturarven (2003). København: Kulturministeriet, p. 10).

5. Fx Københavns Museums litterære audiowalks om Vesterbro, som kan downloades på egen mp3-afspiller: http://www.copenhagen.dk/dk/besog_museet/ude_i_byen/vesterbro_site_en_audiowalk.

6. Struer Museums Byskriveren: http://www.byskriveren.dk/web/default.aspx. Københavns Museums VAGGEN: http://www.vaeggen.copenhagen.dk/.

7. Museets foranderlighed understreges desuden af, at UNESCO-organisationen ICOM (International Council of Museums) løbende ændrer deres definition af et museum, så den følger med samfundsudviklingen: http://icom.museum/the-vision/museum-definition/.

\section{Referencer}

Andersen, J. (2009). Kulturarv er budskabet. En medieteoretisk diskussion af digital formidling af kulturarv. In Niels D. Lund m.fl. (Eds.), Digital formidling af kulturarv. Fra samling til sampling (pp. 65-79). København: Forlaget Multivers.

Andersson, G. (Ed.). (2004). Reinventing the museum. Historical and contemporary perspectives on the paradigm shift. Lanham: AltaMira Press.

Bolter, J.D., \& Grusin, R. (1999). Remediation. Understanding New Media. Cambridge: MIT Press.

Bruhn Jensen, K. (2000). We have always been virtual. Paper presented at Internet Research 1.0: The State of the Interdiscipline, First Conference of the Association of Internet Researchers. University of Kansas, Lawrence KS, USA, september 14-17 2000

Brøgger, A. (2009). Brug af de globale medier lokalt. In A S.W. Løssing (Ed.), Digital formidling i brugerperspektiv (pp. 59-65). København: Kulturarvsstyrelsen.

Cameron, F. (2003). Digital futures I: Museum collections, users, information needs, and the cultural construction of knowledge. Curator, 46 (3), 325-340.

Cameron, F., \& Kenderdine, S. (Eds.) (2007). Theorizing Digital Cultural Heritage. A Critical Discourse. Cambridge: MIT Press.

Christensen, H.D. (2009). Digitale forskydninger. Hvorfor bevare den fysiske kulturarv, når den kan digitaliseres? In N.D. Lund m.fl. (Eds.), Digital formidling af kulturarv. Fra samling til sampling (pp. 99-125). København: Forlaget Multivers.

Ciolf, L., Bannon, L. J., \& Fernström, M. (2008). Including visitor contributions in cultural heritage installations: designing for participation. Museum Management and Curatorship, 23 (4), 353-365. 
Couldry, N. (2007). Communicative entitlements and democracy: The future of the digital divide debate. In R. Mansell et al. (Eds.) The Oxford Handbook of Information and Communication Technologies (pp. 383403). Oxford \& New York: Oxford University Press.

Drotner, K. m.fl. (Eds.). (2011). Det interaktive museum. Frederiksberg C: Samfundslitteratur.

Falk, J.H., \& Dierking, L.D. (1998). Understanding Free-Choice Learning: A Review of the Research and its Application to Museum Web Sites. In D. Bearman and J. Trant (Eds.), Museums and the Web 98. Archives and Museum Informatics. USA. Konsulteret 10. december 2012, http://www.museumsandtheweb.com/ mw98/papers/dierking/dierking_paper.html.

Falk, J.H., \& Dierking, L.D. (2000). Learning from museums. Visitor experiences and the making of meaning. Lanham: AltaMira Press.

Federspiel, B.K. (2012). Kulturarv. Et begreb til forhandling. Nordisk Museologi, 1, 4-19.

Frost, O.C. (2010). When the Object is Digital. Properties of Digital Surrogate Objects and Implications for Learning. In R. Parry (Ed.), Museums in a Digital Age (pp. 237-246). London and New York: Routledge.

Heath, C., \& Lehn, D. vom (2010). Interactivity and collaboration. New forms of participation in museums, galleries and science centers. I R. Parry (Ed.), Museums in a Digital Age (pp. 266-280). London and New York: Routledge.

Hein, G.E. (1998). Learning in the museum. London: Routledge.

Hein, H. (2000): The museum in transition. A philosophical perspective. Washington \& London: Smithsonian Institution Press.

Henning, M. (2006). Museums, media and cultural theory. Open University Press: New York.

Hepp, Andreas (2009): Differentiation. Mediatization and Cultural Change. In K. Lundby (Ed.) Mediatization.

Concept, Changes, Consequences (pp. 139-157). New York: Peter Lang.

Hepp, A., Berg, M., \& Roitsch, C. (2011): Monothematic and multithematic horizons of mediatized communication. Patterns of communicative networking and mediated belonging. Studies in Communication Media (SCM), 2, 1-34.

Hjarvard, S. (2008a). En verden af medier. Medialiseringen af politik, sprog, religion og leg. Frederiksberg C: Samfundslitteratur.

Hjarvard, S. (2008b). The mediatization of society. A theory of the media as agents of social and cultural change. Nordicom Review, 29 (2), 105-134

Hooper-Greenhill, E. (2004). Changing values in the art museum - rethinking communication and learning. In B. M. Carbonell (Ed.), Museum Studies - An Anthology of Contexts (pp. 556-575). Oxford: Blackwell Publishing.

Howes, D.S. (2007). Why the internet matters. A museum educator's perspective. In H. Din \& P. Hecht (Eds.), The Digital Museum. A Think Guide (pp. 67-77). Washington DC: The American Association of Museums.

Huyssen, A. (2003). Present Pasts: Urban Palimpsests and the Politics of Memory. California: Stanford University Press.

Huyssen, A. (1995). Twilight Memories: Marking Time in a Culture of Amnesia. New York \& London: Routledge.

Ingemann, B., \& Larsen, A.H. (Eds.). (2005). Ny Dansk Museologi. Århus: Aarhus Universitetsforlag.

Jensen, J.F. (1997): Interaktivitet. På sporet af et nyt begreb i medie- og kommunikationsvidenskaberne. Mediekultur, 13 (26), 40-55.

Keitel, M.A. (2010). The Role of Interactive Technologies in Designing Meaningful Exhibition Experiences: An Informing Design Probe. The International Journal of the Inclusive Museum, 2 (4), 91-109.

Krotz, F. (2005). Changing Worlds by the Upcoming of Interactive Media. A Study on Entertainment Robots People Use at Home and the Future Role of Interactive Media. Paper presented at the First European 
Communication Conference 2005. Konsulteret 10. december 2012, http://www.uni-erfurt.de/uploads/ media/Projekt_AIBO.pdf.

Krotz, F. (2007). The meta-process of 'mediatization' as a conceptual frame. Global Media and Communication 2007, 3 (3), 256-260. Konsulteret 10. december 2012, http://learningspaces.org/files/nms/Krotz medialisation_metaprocess.pdf.

Kulturministeriet (2009). Digitalisering af kulturarven - endelig rapport fra digitaliseringsudvalget. København. Konsulteret 10. december 2012, http://kum.dk/Documents/Publikationer/2009/Digitalisering\%20 af\%20kulturarven/pdf/digitalisering_af_kulturarven.pdf.

Kyed, S. m.fl. (2006): Udredning om museernes formidling. København: Kulturministeriet. Konsulteret 10. december 2012, http://kum.dk/Documents/Publikationer/2006/Udredning\%20om\%20museernes\%20 formidling/PDF/Udredning\%20om\%20museernes\%20formidling.pdf.

Larsen, A.H. (2001). Museologi som videnskab eller en praktisk redskabsdiciplin?! En skitse over dens aktuelle situation i Danmark. Passepartout. Skrifter for kunsthistorie, 17 (9), 11-20. Aarhus Universitet.

Lumley, R. (Ed.). (1988). The Museum Time-Machine. London \& New York: Routledge.

Lievrouw, L.A., \& Livingstone, S. (2006). Introduction to the Updated Student Edition. In L.A. Lievrouw \& S. Livingstone (Eds.). The Handbook of New Media. Social Shaping and Social Consequences of ICTs (pp. 1-14). London: SAGE Publications Ltd.

Livingstone, S. (2009). On the mediation of everything. ICA Presidential address 2008. Journal of Communication, 59 (1), 1-18.

Lund, N.D. (2009). Digitalisering som kulturpolitik. Agendaer og aktører i den nye formidling af fortiden. In N.D. Lund m.fl. (Eds.), Digital formidling af kulturarv. Fra samling til sampling (pp. 15-40). København: Forlaget Multivers.

Lundby, K. (2009). Introduction. Mediatization as Key. In K. Lundby (Ed.), Mediatization. Concept, Changes, Consequences (pp. 1-18). New York: Peter Lang.

Løssing, A. (Ed.). (2009): Digital museumsformidling i brugerperspektiv. København: Kulturministeriet.

McMillan, S. (2006). Exploring Models of Interactivity from Multiple Research Traditions. Users, Documents and Systems. I L.A. Lievrouw \& S. Livingstone (Eds), The Handbook of New Media. Social Shaping and Social Consequences of ICTs (pp. 205-229). London: SAGE Publications Ltd.

Moos, T., \& Lundgaard, I. (2010.). Museernes webbrugere: en brugerundersøgelse af museernes hjemmesider. København: Kulturarvsstyrelsen. Konsulteret 10. december 2012, http://www.kulturarv.dk/fileadmin/ user_upload/kulturarv/museer/dokumenter/Netbrugerrapport_web_11112010.pdf.

Mordhorst, C., \& Wagner Nielsen, K. (1997). Formens semantik - en teori om den kulturhistoriske udstilling. Nordisk Museologi 1, 3-18.

Nielsen, J. (2006). Participation Inequality: Encouraging More Users to Contribute. Konsulteret 10._december 2012, http://www.useit.com/alertbox/participation_inequality.html.

Paris, S.G. (2006). How Can Museums Attract Visitors in the Twenty-first Century. In H.H. Genoways (Ed.), Museum Philosophy for the Twenty-first Century (pp. 255-266). Oxford: AltaMira Press.

Parry, R., \& Sawyer, A. (2005). Space and the machine. Adaptive museums, pervasive technology and the new gallery environment. In S. MacLeod (Ed.), Reshaping Museum Space. Architecture, Design, Exhibitions (pp. 39-52). London \& New York: Routledge.

Parry, R., \& Arbach, N. (2007). Localized, Personalized, and Constructivist. In F. Cameron \& S. Kenderdine (Eds.), Theorizing Digital Cultural Heritage. A Critical Discourse (pp. 281-298). Cambridge: MIT Press.

Rudloff, M. (2012). Extending Museum Walls. Reaching out with site-specific, digital, and participatory interventions. Nordisk Museologi, 1, 35-55.

Schulz, W. (2004). Reconstructing Mediatization as an Analytical Concept. European Journal of Communication, 19 (1), 87-101. 
Smith, C.S. (2006). The Future of the Museum. In S. Macdonald (Ed.), A Companion to Museum Studies (pp. 543-554). Oxford: Blackwell Publishing.

Simon, N. (2010). The Participatory Museum. Museum 2.0: Santa Cruz. Konsulteret 10. december 2012, http://www.participatorymuseum.org/read/.

Skot-Hansen, D. (2009). Digital formidling i danske museer - udfordringer for oplevelsessamfund og oplevelsesøkonomi. In N.D. Lund m.fl. (Eds.), Digital formidling af kulturarv. Fra samling til sampling (pp. 43-63). København: Forlaget Multivers.

Skouvig, L. (2009). Troværdighed eller Buzzword. Diskursen om autenticitet. In N.D. Lund m.fl. (Eds.), Digital formidling af kulturarv. Fra samling til sampling (pp. 81-96). København: Forlaget Multivers.

Taylor, B.L. (2010). Reconsidering digital surrogates. Toward a viewer-orientated model of the gallery experience. In S.H. Dudley (Ed.), Museum Materialities. Objects, Engagements, Interpretations (pp. 175-184). Oxon and New York: Routledge.

Vergo, P. (1989). Introduction. In P. Vergo (Ed.), The New Museologi. London: Reaction Books Ltd.

Witcomb, A. (2006). Interactivity. Thinking Beyond. In S. MacDonald (Ed.), A Companion to Museum Studies (pp. 353-361). Oxford: Blackwell Publishing Ltd.

Witcomb, A. (2007). The Materiality of Virtual Technologies. In F. Cameron \& S. Kenderdine (Eds.), Theorizing Digital Cultural Heritage. A Critical Discourse (pp. 35-48). Cambridge: MIT Press.

Maja Rudloff

Ph.d.-stipendiat

Afdeling for Medievidenskab

Institut for Kulturvidenskaber

Syddansk Universitet, Danmark

maru@sdu.dk 